\begin{tabular}{|c|c|c|c|}
\hline Article Info & RESEARC ARTICLE & ARAŞTIRMA MAKALESİ & \\
\hline Title of Article & $\begin{array}{r}\text { LAW } 6360 \text { : } \\
\text { From Centralis }\end{array}$ & $\begin{array}{l}\text { nd I ts Critique: } \\
\text { n to Re-Centralism }\end{array}$ & 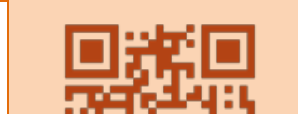 \\
\hline $\begin{array}{l}\text { Corresponding } \\
\text { Author }\end{array}$ & \multirow{3}{*}{\multicolumn{2}{|c|}{$\begin{array}{l}\text { Şahin ALATAŞ } \\
\text { İstanbul Üniversitesi Sosyal Bilimler Enstitüsü, sahinalatas34@gmail.com } \\
\text { 24/07/2019 / 10/09/2019 } \\
\text { ALATAŞ Ş., (2019). Makale Adı, 6360 Sayılı Kanun ve Bu Kanunun Eleştirisi: } \\
\text { Merkeziyetçilikten Yeniden Merkeziyetçiliğe Kent Akademisi, Volume, } 12 \text { (39), Issue 3, } \\
\text { Pages, 488-500 }\end{array}$}} & 1 \\
\hline $\begin{array}{l}\text { Submission Date } \\
\text { Admission Date }\end{array}$ & & & \\
\hline How to Cite & & & $\begin{array}{c}\text { ORCID NO: } \\
0000-0002-7876-601 x\end{array}$ \\
\hline
\end{tabular}

\title{
6360 Sayılı Kanun ve Bu Kanunun Eleştirisi: Merkeziyetçilikten Yeniden Merkeziyetçiliğe
}

\section{ABSTRACT:}

An issue which will be governed by the model of the big cities in Turkey, date back to the Ottoman Empire period as well. With the increase in the number of cities where the population is concentrated intensively, the problems experienced in these cities have increased and the management problem has been kept up to the date. The foundation of the metropolitan municipality system in Turkey was created by the 1982 Constitution. After the Law No. 3030 which entered into force in 1984, the Law on Metropolitan Municipality 5216 was accepted in 2004. Following this law, it was amended with the Law No: 5747 in 2009 and the Law No: 6360 in 2012.

Law No. 6360 caused a lot of discussion in Turkey and has been criticized by some circles. In this study, the evaluation of the Municipality Law No. 6360 was evaluated and the criticisms brought to the law were examined.

KEYWORDS: Law No. 6360, local governments, metropolitan municipality laws,

ÖZ:

Türkiye'de büyük şehirlerin hangi model ile yönetileceği sorunu, Osmanlı dönemine kadar uzanmaktadır. Nüfusun yoğun olarak toplandığ şehirlerin sayısının artmasıyla bu şehirlerde yaşanan problemler artmış ve yönetim sorunu güncelliğini korumuştur. Türkiye'de büyükşehir belediye sisteminin temeli 1982 Anayasası ile oluşturulmuştur. Sonrasında 1984 yılında yürürlüğe giren 3030 Sayılı Kanun sonrası 2004 yılında 5216 Sayılı Büyükşehir Belediye Kanunu kabul edilmiştir. Bu kanuna sonrasında 2009 yılında 5747 Sayılı Kanun ve 2012 yılında 6360 Sayılı kanun ile değişikliğe uğramıştır.

6360 Sayılı kanun Türkiye'de birçok tartışmaya neden olmuş ve bazı çevrelerce eleştirilmiş̧tir. Bu çalışmada 6360 Sayılı belediye kanununun değerlendirmesine yer verilerek kanuna getirilen eleştiriler incelenmiştir.

ANAHTAR KELIMELER: 6360 Sayılı Kanun, Yerel Yönetimler, Büyükşehir Belediye Yasası

\footnotetext{
${ }^{1}$ İ.Ü. Sosyal Bilimler Enstitüsü Yüksek Lisans Öğrencisi, sahinalatas34@gmail.com
} 


\section{GíRiş}

Tüm dünyada ekonomik, teknolojik ve sosyo/kültürel alanlardaki gelişmeler hemen her alanda olduğu gibi yönetim anlayışının da değişimine neden olmuştur. Şehirler, dijital dünyada yaşanan gelişmeler sonrasında, ekonomik, sosyal, kültürel ve politik alanlarda hızlı bir değişim sürecine girmiştir. Böylece ülkeler için şehirlerin yönetim anlayışında değişime gitmek kaçınılmaz olmuştur.

Ülkelerin yönetim biçimleri, kendi değerleri ve alt yapıları ile biçimlenmektedir. Uzun yıllar üniter ve merkeziyetçi bir yönetim anlayışına sahip olan Türkiye'de 2000'li yıllardan itibaren adem-i merkeziyetçiliğin öne çıkarıldığı bir yönetim anlayışı modeli benimsenmeye çalışılmıştır. $\mathrm{Bu}$ anlayış ile yerel yönetimler konusunda kanuni düzenlemeler yapılmış ve farklı sistemler denenmiştir. Bu düzenlemelerden en fazla etkilenen birimler, metropol olarak adlandırılan büyükşehirler olmuştur. 1982 Anayasası'nda (127. Madde) “'büyük yerleşim yerleri için özel yönetim biçimleri getirilebilir' hükmü bulunmaktadır. Bu hüküm çerçevesinde büyükşehir belediyeleri 1984 yılında kamu yönetimi sistemine dahil edilmiştir. 2004 yılında çıkarılan 5216 sayılı kanun ile ise il mülki sınırı içinde büyükşehir belediyesi modeline geçilmiş (İstanbul ve Kocaeli) ve bazı önemli düzenlemeler yapılmıştır. 2012 yılına gelindiğinde ise, il mülki sınırları içinde hizmet sunumu öngören bu sistem 6360 Sayılı On Dört İlde Büyükşehir Belediyesi ve Yirmi Yedi İlçe Kurulması ile Bazı Kanun ve Kanun Hükmünde Kararnamelerde Değişiklik Yapılmasına Dair Kanun ile genişletilerek yürürlüğe konulmuştur. Bu kanun ile ayrıca 14 yeni büyükşehir belediyesi kurulmuş ve yerel yönetim anlayışında köklü değişikliklere gidilmiştir.

2014 yerel seçimlerinin ardından uygulamaya konulan yeni büyükşehir modelinin, pratikte siyasi, idari, sosyal ve kentsel birtakım etkileri gözlemlenmiştir. Bu çalışmada, 6360 Sayılı kanun ile ilgili bilgi verilerek, yasaya getirilen eleştiri ve değerlendirmelere değinilmiştir.

\section{6360 Sayılı Yasanın Genel Hatları Ve Değerlendirmeler}

Türkiye Cumhuriyeti'nin halen yürürlükte olan 1982 Anayasası'nda yerel yönetimlerin tanımlanması yapılmıştır. 127. Maddede yapılan bu tanıma bakıldığında yerel bölgelerde yerel yönetimlerin aktif rol oynadığı görülmektedir. Yine aynı maddede (3. Fıkra) büyük yerleşim yerleri için özel yönetim birimleri getirilebilir şeklinde bir ifade bulunmaktadır. Böylece ilk kez 1984 yılında 3030 Sayılı Kanun ile BŞB (Büyükşehir Belediyeleri) kurulmuştur (Karaaslan, 2013:129). 2004 yılına gelindiğinde ise 5216 sayılı Büyükşehir Belediyesi Kanunu yürürlüğe girmiştir. $\mathrm{Bu}$ kanun ile belde belediyeleri büyükşehirlerin sınırlarına dahil edilerek BŞB'ne yakın olan ilçe belediyeleri büyükşehirlerin ilçe belediyeleri haline getirilmişlerdir. Bunun yanında büyükşehir olma şartı değiştirilerek nüfusun 750.000 ve üzeri olması kriteri getirilmiştir (Karaaslan, 2013:132). BŞB’leri ile ilgili olarak son kanun düzenlemeleri 2012 yılında yapılmış 6360 Sayılı Büyükşehir Belediyesi Kanunu ile 2013 yılındaki 6447 Sayılı Kanunlardır. 6447 Sayılı Kanun ile 6360 Sayılı Kanunun temel hükümleri korunmuş ve bazı kısmi değişiklikler getirilmiştir.

6360 Sayılı Kanun kapsamında 14 ilde bulunan il belediyeleri BŞB’ne dönüştürülmüştür. 6447 Sayılı Kanun kapsamında Türk yerel yönetim sisteminde en son olarak Ordu ili BŞB olmuştur. Böylece yeni kurulan BŞB ile birlikte Türkiye'de BŞB sayısı 30'a yükselmiştir (Tekin, 2018:88). 6360 Sayılı Kanun uyarınca bu 30 BŞB'nin yetki ve sorumluluk alanları il mülki sınırlarına kadar genişletilmiş ve böylece bu BŞB'nin yetki ve sorumlulukları 
artmıştır. Ayrıca 6360 Sayılı Kanun ile bütün bu büyükşehirlerde bulunan belde belediyeleri ve köylerin tüzel kişiliklerine son verilmiştir. Köyler mahalle, belediyeler ise belde isimleri ile tek mahalle şeklinde bağlı oldukları ilçe belediyelerine dahil edilmişlerdir. Aynı zamanda bu illerdeki bucak teşkilatları da kapatılmıştır. Bu illerde bulunan il özel idarelerinin tüzel kişiliği ile İstanbul ve Kocaeli’ndeki orman köyleri de dahil tüm köylerin tüzel kişiliğine son verilmiştir. Bunun yanında, valiliklere bağlı olmak kaydı ile 30 ilde "Yatırım İzleme ve Koordinasyon Başkanlı̆̆ı" kurulmuş ve merkezi yönetimin paylarına ilişkin tekrar düzenleme yapılmıştır.

6360 Sayılı Kanun’un yürürlüğe girmesiyle birlikte; illerin imar bütünlüğünü sağlaması açısından, mekânsal planlamaya göre daha önce düzenlenen ve pergel yasa olarak adlandırılan yasaya oranla daha fazla avantaj sağlaması açısından ve de etkinlik ve verimliliğin ve artması beklentisinden dolayı avantajlar sağladığı düşünülmektedir. Diğer yanda ise, 6360 sayılı Yasa beraberinde birçok yerel yönetim birimi sona erdiği için yerel özerkliği, katılımı ve yerindelik dene-timini sekteye uğratmaktadır. Bunun yanı sıra İstanbul ve Kocaeli modelinde olduğu gibi tek tipleşen ve çeşitliliğin olmadığı bir büyükşehir belediye sistemini öngörmektedir. Anayasanın 126. Maddesi Türkiye’nin il idareleri ve yetki genişliği esasına dayalı olduğunu söylemektedir. 127. maddesine göre ise il, belediye ve köylerde yaşayan halkın mahallî gereksinimlerinin "mahalli idareler" tarafından karşılanacağı öngörülmektedir. Ancak bu haliyle bu hizmetlerin tek bir mahalli idarenin karşılayacağı söylenmiştir. Bu haliyle il özel idarelerinin 27 ilde kaldırılması Anayasa'ya aykırılık taşımaktadır. Bunun yanında il özel idarelerinin 51 şehirde bırakılması ve 30 büyükşehirde kapatılması da ikili bir durum doğurmuştur. Ayrıca yeni düzenlemede büyükşehirlerdeki vergi tabanı farklılaşması da eşit olmayan bir durum yaratmıştır. 6360 Sayılı Kanun ile BŞB’nin yetki ve görev alanları il mülki sınırlarına genişletilerekkırsal alan yönetiminiele almalarına neden olmuş veBŞB, yönetsel anlamda ön plana çıkarılarak mülki idarenin yereldeki etkisi kırılmıştır.Ayrıca yeni düzenlemeyle birlikte BŞB tüm ildeki imar ve planlamayla ilgili düzenlemelerin başlıca sorumlusu tutulmuştur (Tekin, 2018:89).

Aslında, 30 Mart 2014 Yerel Yönetim Seçimleri sonrasında yürürlüğe giren 6360 sayılı Kanun'un getirdiklerini kısaca sıralamak gerekirse(Arıkboğa, 2013:67 - 68; Özer, 2013:114 - 115; Zengin, 2014:102 - 103):

- Belediye olan14 il büyükşehir belediyesine dönüştürülmüştür.

- Yeni düzenlemeyle büyükşehir sayısı otuza çıkmış ve bu büyükşehirlerin sınırları, il mülki sınırlarıyla birleştirilmiştir; ayrıca büyükşehirlere bağlı ilçe belediyelerinin sınırları da ilçe mülki sınırları ile örtüştürülmüştür.

- $\quad 2.000$ 'in altında nüfusa sahip olan 559 belediye, köy yapılmıştır.

- $\quad$ İki kademeli olarak oluşturulan mevcut BŞB sisteminde, en az 2.000 nüfus olması şartına bakılmaksızın, bu sistemden dolayı yeni yapılan BŞB’nin sınırlarının içinde yer alan 1.076 tane belde belediyesi ve 16.500 tane köy tüzel kişiliklerini kaybederek mahalle yapılmıştır.

- $\quad$ Önceleri bir ilin BŞB olabilmesi için belediye sınırlarındaki nüfusun 750.000’i aşması gerekmekteydi. Yeni düzenlemeyle il nüfusunun 750.000’i aşması yeterli kabul edildi.

- Yeni düzenlemeyle BŞB yapılan 14 ilde, BŞB’ye bağlı 25 tane yeni ilçe oluşturulmuş ve bağlılık konusunda değişiklikler yapılarak, toplam 143 olan büyükşehir belediyelerinin ilçe belediyesi 519'a çıkarılmıştır.

- $\quad$ Büyükşehir belediyelerinin ilçe belediyesi olmasının nüfus ölçütü 50.000 iken 20.000'e düşürülmüştür.

- Kapatılarak mahalle yapılan belediye ve köylerle ilişkili devir, tasfiye ve paylaştırma komisyonları kurulmuştur. 
- Yeni haliyle sayıları otuz olan büyükşehir belediyelerinde il özel idareleri ortadan kaldırılmış.

- Ortadan kaldırılmış olan il özel idarelerinin yerine, "Yatırım İzleme ve Koordinasyon Başkanlıkları" kurularak bu başkanlıklar valiliklere bağlanmıştır.

Bu başkanlıklar taşra örgütlenmelerinin içinde konumlandırılmış ve görevleri yasada belirtilmiştir.

\section{Yasanın Getirdiği Mali Hükümlerde Değişiklik}

6360 Sayılı Kanun’un değişiklik öngördüğü diğer bir konu da mali konulardır. Yeni düzenleme ile, genel bütçe vergileri tahsilatının toplamından BŞB'ne ayrılan pay ve BŞB sınırlarında yapılan genel bütçe vergi gelirleri tahsilatının toplamından her bir büyükşehir belediyesinin alacağı oran artmıştır. 5779 Sayılı Kanun’da bütçe ile ilgili olarak yapılan değişiklikler ile daha önce genel bütçe vergi gelirleri tahsilatının toplamından $\% 2,85$ pay alan belediyeler böylelikle \%1,50 oranında pay alacaktır. BŞB'nin oranı ise \%2,50'den \%4,50'ye çıkarılmıştır. Bunun dışında İl Özel İdarelerinin \%1,15 olan payı \%0,5’e çekilmiştir. Kanunun uygulanması bir anda yapılmayarak bir geçiş dönemi düşünülmüş̧ür. Bu geçiş döneminde BŞB'ne bağlanan yerel yönetimler ve bölgede yaşayan halk için hükümler esnetilmiştir. Bunun dışında sürecin sıkıntısız atlatılması için valiliklerin sorumlulukları arttırılmış ve sonradan statüsü değişmiş olan yerel yönetim birimlerine bazı kolaylaştıııcı istisnalar sağlanmıştır (Zengin, 2014:103).

\section{Büyükşehir Belediyesi ve İlçe Belediyesinin Farklııkları}

BŞB sisteminin önemli unsurlardan biri, büyükşehir ilçe belediyesi yapılanması olmuştur. Büyükşehir ilçe belediyeleri, bir ilçe belediyesinden farklı niteliklere sahiptir. Ayrıca büyükşehir belediyesi sınırlarında bulunmayan bir ilçe belediyesinin, herhangi bir belediye ile arasında fark bulunmamakta ve hizmetlerini Belediye Kanunu'na tabi bir biçimde ve herhangi bir idari yapılanmanın (BŞB) altında olmaksızın tamamen kendi başına yürütme yetkisi bulunmaktadır. Oysa BŞB ilçe belediyeleri, hizmetlerinin bir bölümünü BŞB’ne devretmek ve bir bölümünü de BŞB ile birlikte yürütmek zorundadır. Bunun yanında bazı hizmetlerinin de BŞB tarafından onaylanması ve denetlenmesi söz konusudur. Ayrıca ilçe belediyeleri gelirlerinin bir kısmını BŞB'ye devretmek durumunda da kalabilmektedir. 5216 Sayılı Kanun'a göre BŞB ilçe belediyelerinin yapmakla sorumlu olduğu hizmetler şunlardır (Zengin,2014:105);

- Büyükşehir yönetmeliğindeki katı atık planına uygun bir şekilde, katı atıkları toplayarak aktarma istasyonlarına taşımak,

- Sıhhi işyerlerine, 2. ve 3. sınıf gayrisıhhi müesseselerine, halka açık dinlenme ve eğlence yerlerine ruhsat vererek denetlemek,

- Dinlenme, eğlence ve spor yerleri, park, otopark gibi alanları yapmak; yaşlı ve engelli vatandaşlar ile kadınlara, gençler ve çocuklar için kültürel ve sosyal hizmetler üretmek; mesleki eğitim ve beceri alanlarında kurslar düzenlemek; ibadet yerleri ile kültür, sağlık, eğitim tesis ve binaları yapmak, bu binaların bakım ve onarımlarıyla ilgilenmek; kültür ve tabiat varlıklarının ve tarihi dokunun korunması çalışmaları yürütmek; kentin tarihi açısından önemi olan mekanların ve işlevselliklerinin geliştirilmesi için hizmetlerde bulunmak,

- Cenaze ve defin hizmetlerini yürütmek,

\footnotetext{
${ }^{2} 5779$ Sayılı İl Özel İdarelerine ve Belediyelere Genel Bütçe Vergi Gelirlerinden Pay Verilmesi Hakkında Kanun
} 
- Can ve mal güvenliğini tehdit eden veya afet riski taşıyan binaları tahliye ederek yıkmak.

İlçe belediyeleri ve büyükşehir belediyeleri arasındaki ilişkiye bakıldığında, büyükşehir belediyelerinin, ilçe belediyelerindeki imar uygulamalarını denetleme yetkisi olduğu göze çarpmaktadır. Denetim yetkisi; konuyla ilgili olan tüm bilgi ve belgeleri istemek, incelemek şeklindedir. İlçe belediye meclisleri tarafindan imara ilişkin alınan kararlar, üç ay içinde BŞB'nin meclisi tarafından incelenerek (nazım imar planına açısından) aynen veya üzerinde değişiklik yapılarak kabul edilir ve BŞB başkanına gönderilir. Bunun yanında ilçe belediyeleri bütçe konusunda da sınırlandırılmıştır. Vergi gelirleri toplamından BŞB’ye aktarılan pay, ilçe belediyeleri üzerinden aktarılmaktadır. Ayrıca ilçe belediyeleri gelirlerinin \%40’ını da BŞB’ne aktarmak zorundadır. 5216 Sayılı Kanun’a göre BŞB hizmetlerinin bir bölümünü, ilçe belediyelerine devredebilir veya bu hizmetleri onlarla birlikte yürütme kararı alabilir. $\mathrm{Bu}$ doğrultuda BŞB;

a) Yolcu ve yük terminalleriyle açık ve kapalı otoparkların yapımı, yaptırılması, işletilmesi veya işlettirmesi ve ruhsatının verilmesi;

b) Mezarlık için alanlar tespit ederek tesis etmek, işletmek, bir başkasına işlettirmek ve defin hizmetlerini yürütmek;

c) Her türden toptancı hallerinin ve mezbahaların yapımı, yaptırılması, işletilmesi veya işlettirmesi, imar planında belirlenen yerlerde yapılması planlanan özel hal ve mezbahaların ruhsatlandırması ve denetlenmesi, temizlik hizmetleri, adres ve numaralandırma işlemleri gibi hizmetleri, belediye meclisi kararı sonucu kendisine bağlı bulunan ilçe belediyelerine devredebilir veya bu hizmetleri beraberce yürütebilirler.

İlçe belediyelerinin büyükşehir belediyelerine gerek hukuken gerekse yönetsel olarak bu türden bağlılığı, her iki yönetim biriminin bağlı olduğu siyasi partinin veya sahip olunan siyasi görüşün kesişip kesişmemesine göre uygulama aşamasında farklı sonuçlar ortaya çıkmaktadır. Bir ilde Büyükşehir belediyesi ile ilçe belediyesi aynı partiye mensup ise iki belediye arasındaki işbirliği düzeyi artmakta ve idari ve maddi destek konularında daha az problem yaşanmaktadır. Tersi bir durumda ise ilçe belediyelerinin, BŞB tarafından desteklenmemesi, dahası hizmet üretme ve sunma konusunda ilçe belediyesine köstek olunması durumlarıyla bile karşılaşılabilmektedir. Bu ikili durum, Türkiye'de çoğu zaman, yönetsel birimlerin görev ve sorumluluklarını nasıl yerine getireceği konusunda belirleyici unsur olmaktadır. Öncelikle ilçe belediyeleri, sonrasında ise bütün belediyeler için önemli bir diğer konu da, yetki alanı/belediye sınırları ile ilgilidir. 6360 Sayılı Kanun öncesinde mülki idare sınırları ile belediye sınırları birbiriyle çakışmıyordu. Belediyelerin sınırları, kent merkezini; bir ilin ya da ilçenin (mülki) sınırları ise kırsal bölgeyi de içine alacak şekilde daha büyük bir alanı kapsıyordu. 5216 Sayılı Kanun ile 'pergel düzenlemesi' ne gidilerek bu kural esnetilmeye çalışılsa da hala geçerliydi. Ancak yeni kanun ile BŞB'de, ilçe belediyeleri sınırları, ilçe mülki sınırlarıyla çakıştırılmıştır. Böylelikle BŞB ve ilçe belediyeleri daha geniş bir alanda yetki ve sorumluluk sahibi haline gelmişlerdir. Bunun yanında seçim çevresi de böylece değişmiştir. 6360 Sayılı Kanun’un yürürlüğe girmesinin ardından önceleri kendi halinde ilçe belediyeleri olan belediyelerin, birdenbire BŞB ilçe belediyesine dönüşerek bir nevi boyunduruk altına girmiş olmaları, reform düzenlemesinde tepki çeken ve riskli görülen noktalardan biri olmuştur.

\subsection{Sayılı Kanuna Getirilen Eleştiriler}

6360 Sayılı Kanun'un çıkarılma sebebi, daha önce yapılan reform düzenlemelerindeki gibi; imar-plan bütünlüğüyle, hizmetlerin etkinlik ve verimliliğinin attırılması, kaynak israfını önlemek için yönetsel kapasitesi yetersiz olan yerel yönetim birimlerinin kapatılması, görev çakışmalarının engellenmesi vb. nedenlerdir. Ana muhalefet partisinin 
Anayasa Mahkemesi'ne açmış olduğu iptal davasının (harcamalara katılım bedelinin alınıp alınmayacağına dair hüküm dışında) reddedilmesinin üzerine kanun, 2014 yerel seçimleri sonrası yürürlüğe girmiştir. Kanun için açıklanan hukuki ve akademik gerekçelerin bir bölümü haklı görülmektedir. Siyasilerin popülist yaklaşımları sonucunda Türkiye'de (daha ziyade 1980 sonrası) pek çok suni il, ilçe ve belediye birimi oluşturulmuştur. Bu yerleşim yerlerindeki yönetsel birimlerindeki yönetsel birimler yüklendikleri sorumlulukları yerine getirmek konusunda yetersizdir. Hatta bazen bu suni yerel yönetim birimleri, bir yerleşim bölgesindeki mevcut olan yönetim biriminin parçalanmasıyla meydana getirilmişlerdir. Böylece bir yerleşim bölgesinde birden çok yönetsel birim ortaya çıkmıştır (Çınar, vd., 2013:78-82).Bu durum, planlamadan hizmet sunmaya kadar birçok önemli konuda sorun yaşanmasına neden olmuştur. Bunun yanında sayıca fazlalaşan bu yönetim birimlerinin idari ve mali kapasitelerinin yetersizliği, hizmet götürme konusunda sorunlar yaşadığı, bütçeleriyle anca personellerinin giderlerini karşılayabildikleri, nitelikli personel barındıramadıkları görülmüştür. Her ne kadar bazı konularda yapılan saptamalarda gerçeklik payı bulunsa da reform süreci boyunca sergilenen düşünme tarzı ve bununla birlikte yapılan somut düzenlemeler ve uygulamalarında eleştiriye açık birçok husus göze çarpmaktadır. Bu hususlar aşağıda incelenmiştir.

\subsubsection{Bilimsel Hazırlık Yapılmaması}

Yeni büyükşehir belediyesi düzenlemesi ile ilgili olarak herhangi bir bilimsel bir ön çalışma/fizibilite hazırlığı veya farklı ülkelerdeki örnekleri içeren karşılaştırmalı bir analiz raporuna rastlanmamıştır. Bunun yanında düzenleme için dile getirilmiş olan gerekçe ve gösterilen hedeflerin tam tersi ile karşılaşılabilme ihtimali doğuran pek çok içerik barındırmaktadır. Kanun zamanla ek düzenlemeler yapılmasına ihtiyaç duyulacak şekilde düzenlenmiştir. Bu açıdan bakıldığında seçim çevrelerine yönelik yapılan siyasal bir çaba gibi durmaktadır (Tekin, 2018:90).

\subsubsection{Bütünşehir Adlandırması}

Gerek iktidar sahipleri gerekse muhaliflerce oluşturulan ve genel kabul gören 'bütünşehir' adlandırması doğru değildir. 'Bütünşehir' adlandırması, BŞB sınırlarıyla il mülki idare sınırları çakıştırılarak ortaya çıkarılmış yeni BŞB yönetim modelini ifade etmektedir. Bütünşehir (unicity) adlandırması ilk kez 12 Eylül darbesinden sonra sıkıyönetim döneminde ortaya çıkmıştır. Büyük kentlerle ilgili olarak ayrı bir düzenlemeye gidilmeden önce ${ }^{3}$, anakentlerin çevresinde bulunan küçük belediyelerin, imar, ulaştırma, su aydınlatma, kanalizasyon vb. hizmetleri bölge halkına yeterli oranda götürememesi ve anakentlerin kontrol ve iç güvenlik hassasiyeti nedeniyle yapılan iki düzenleme, bu tanımı doğurmuştur (Can, 2013:267). Bu iki düzenleme ile anakentler ve orta büyüklükteki kentlerin çevresinde bulunan birçok belediye ve köyün tüzel kişiliklerini kaldırmış ve büyük belediyeye bağlamıştır.

"Bütünşehir” terimi esasen, merkezdeki büyük olan belediyenin, çevresindeki küçük yerel yönetim birimlerini bünyesine katarak genişlemesi üzerine bir durumu ifade etmektedir. Bu terim olumlayıcı bir çağrışım yaratsa da içerik ve uygulanış açısından tartışmalıdır. Diğer yandan, büyükşehir belediyesi konusunda yapılan reformu eleştiren muhalif kesimlerin bu terime sahip çıkarak kullanması da dikkat çekicidir (Zengin, 2014:111).

\subsubsection{Optimal Hizmet Alanı}

Optimal hizmet alanı, bütünşehirin ilçelerinde bir hizmetin en kaliteli olarak verilebilmesi için hizmetin verileceği bölgenin nüfusunun ve coğrafi uzaklığının gözetilmesini ifade etmektedir. Yeni yasa ile optimal hizmet alnı

\footnotetext{
${ }^{3} 1984$ tarihli 3030 Sayılı Kanun
} 
gözetilmemiştir. Örneğin Çanakkale 130 bin nüfuslu bir ilken, 891 bin nüfuslu Esenyurt gibi kalabalık bir ilçeye veya 120 bin nüfuslu Kanarya mahallesine kaliteli hizmet vermek mümkün görünmemektedir. Bunun yanında kırsal alanı çok fazla olan illere hizmet götürmek de yeni yasa ile zor hale gelmiştir. Örneğin Ordu ilinin BŞB'nin 130km uzaklıktaki Aybastı ilçesine yol götürmesi zorlaşmıştır. Bütünşehir planı kırsalın çok olduğu, şehirleşmenin dağınık olduğu illerin durumu gözetilmeden hazırlanmıştır. Bu gibi illerde yerelin bütüne toplanması hizmet kalitesi açısından önemli sıkıntılar doğurmaktadır. Örneğin Diyarbakır BŞB’nin kendinden 150km uzaklıktaki bir ilçenin temizlik, su, kanalizasyon, yol vb. hizmetlerini aksatacağı ortadadır. Özellikle Karadeniz, İç Anadolu, Ege ve Doğu Anadolu gibi kırsalın fazla olduğu, coğrafi olarak uzak, nüfusun yüksek olduğu, mezraların bulunduğu bölgelerde, bütünşehir anlayışıyla kaliteli hizmet götürmek mümkün değildir (Anas ve İnci, 2014:10).

\subsubsection{Anayasaya Aykırılık}

Yeni kanun, anayasaya ve temel kanunlara uygun olup olmadığı açısından da sorgulanmıştır. Üçlü yerel yönetim sisteminin (il özel idaresi, belediye ve köy) anayasal ve yasal bakımdan zorunlu olması, BŞB’ye ait alanların yerleşim yerleri olmaktan çıkarılması, yönetim birimlerinin yerel halkı temsil etmesi zorunluluğu, yönetim birimlerinin, mesafe baz alınarak tanımlanamaz duruma gelmesi gibi konularda anayasaya ve yasalara aykırılık taşıdığı iddiaları gündeme gelmiştir (Tekin, 2018:92).

\subsubsection{Yerel özerkliğe uygunluk}

Belediye ve köylerin kapatılması sırasında yerel özerkliğe ve (yerel) demokrasiye karşıı bir tutum sergilenmiş ve herhangi bir referandum yapılarak yerel halkın fikri alınmamıştır. Bu uygulama ile Türkiye Cumhuriyeti Hükümeti olarak imzaladığımız Avrupa Yerel Yönetimler Özerklik Şartı'nın 5. Maddesine aykırı durmaktadır. Bu madde; "Yerel yönetimlerin sınılarında, mevzuatın elverdiği durumlarda ve mümkünse bir referandum yoluyla ilgili yerel topluluklara önceden danışılmadan değişiklik yapılamaz” demektedir (Zengin, 2014:111).

\subsubsection{Demokratik Katılımın Azalması}

Yeni düzenleme ile temsilî demokrasinin azaltıldı̆̆ı, etkinlik - verimlilik gerekçesiyle siyasî ve demokratik katılımın daraltıldığı savunulmuştur. Güler (2012) bu düzenleme ile, Türkiye'de doğrudan halk tarafından seçilmiş olan yaklaşık 250.000 seçilmişin sayısının 200.000'e düşürüldüğünü belirtmiştir. Bunun yanı sıra bu düzenleme sonrası seçilmişlerin etkinlik gücünde yetki ve güç bakımından erime yaşanmıştır. Vatandaşların tabandan hareket yeteneği ve siyasal temsili zarar görmüştür (Güler, 2012).

\subsubsection{Temsiliyet Sorunu}

Yeni düzenleme ile yerel halkın temsiliyet yapılanması sorunludur. Kanun ile binlerce belediye mahalleye dönüştürülmüş ve böylece o bölgedeki halkın seçmiş olduğu karar organları da kapatılmıştır. Öte yandan, kent merkezlerinden uzakta yaşayan ve hiçbir bağı bulunmayan yerel halkın kanun sonrası bağlandıkları anakentin karar organlarının oluşumunda ve temsiliyetinde yer alacak olmaları da sorunlu bir durum olarak görülmüsstür (Zengin, 2014:111).

\subsubsection{Hizmete Yakınlık}

Büyükşehir belediyelerinin, konum olarak uzakta bulunan ve sosyo/ekonomik bakımdan az ilişkide olduğu veya hiçbir ilişkisinin bulunmadığı yerleşim birimlerine hizmet götüreceğini öngörmek ve uzakta olan bu yerleşim 
birimlerini de hizmetler açısından ona bağlı kılmak, "halka yakınlık' ilkesiyle uyuşmamaktadır. Bu durum tam aksine BŞB'ler aracılığıyla yeni merkezi yönetimler yaratmak ve merkeziyetçiliği güçlendirmek anlamı taşımaktadır.

$\mathrm{Bu}$ durumun, hizmetlerin aksayarak kalitesinin düşmesine, hizmet sunumdaki sürenin uzamasına, vatandaşın memnuniyet düzeyinin düşmesine ve kaynakların israfına yol açması muhtemeldir (Yıldırım ve Belli, 2013: s. 109).

\subsubsection{Yerinden Yönetim}

İl özel idareleri yerelleşme anlayışına aykırı bir şekilde otuz büyükşehir belediyesinin bünyesinden kaldırılarak bu birimlerin yerine valiliklere bağlanan "Yatırım İzleme ve Koordinasyon Başkanlıkları" oluşturulmuştur. Ayrıca çıkarılan yönetmelikte bu birimlerinn idari yapılanmalarının nasıl olacağı ve işleyişi hakkındaki bilgiler net değildir (Örneğin, mülki ve yerel idarelerin kalkınma ajansları ile olan ilişkisi).

\subsubsection{Kır-kent Ayrımı}

BŞB sınırları il sınırları yapıldıktan sonra gerek sosyolojik açıdan gerekse yönetsel açıdan kır ve kent ayrımı diye bir durum ortadan kalkmıştır. Böylece kent kavramı tanımlanamaz hale gelmiştir.

Yeni düzenleme ile büyükşehirlerin gelirleri artırılarak kapatılan yerel yönetim birimlerinin personel ve araç-gereçleri BŞB'lere devredilmiştir. Buna rağmen BŞB'lerin tüm il sınırlarında yer alan kırsal bölgelerin tamamını kapsayacak bir biçimde kaliteli hizmet götürmesi çok zor görünmektedir. İl özel idarelerinin kaldırılması sonucu, belediyenin sınırları dışında gerçekleşen kırsal hizmetler ile belediye sınırlarının hem içinde hem de dışında sunulan hizmetlerin tümünün BŞB tarafından yerinde, zamanında ve nitelikli bir biçimde nasıl sunulacağı konusu bir başka eleştiri ve merak konusu olmuştur. Daha önce, il özel idareleri, birçok taşra yönetiminin ve yerel yönetim biriminin yapmakla sorumlu olduğu (ihale yapmak, personel, araç/gereç ve kaynak aktarmak vb.) hizmetleri kendi bütçelerine aktarılan ödenekle fiilen üstlenmekteydi. Bunun yanında il özel idareleri, belediyeler gibi oy odaklı değil hizmet odaklı idarelerdi. Bu yeni anlayış, hizmet kalitesi ve vatandaşın memnuniyeti açısından sorunlar yaratabilir (Zengin, 2014:112).

\subsubsection{Köylerin Tüzel Kişiliğinin Kaldırılması}

Yeni düzenleme ile yerel yönetim birimlerinin içerisindeki en köklü ve yerleşik olan köy yönetimleri büyük darbe almıştır. Tarımsal üretim kapasitesinin düşeceği ve zarar göreceği, endişesi yaratmıştır. Köylüye bir nevi zorla kentli gömleği giydirilmiş ve bölgedeki çiftçiler, hukuki, idari ve mali kayıplar yaşayarak kırsal alandaki yaşamını idame ettirmek konusunda zorluk yaşayacaktır. Geleneksel ve doğal yöntemlerle yapılan tarımsal üretim yerine ticarileşmiş tarımsal üretimin yaygınlaşacağı eleştirisi getirilmiştir. Ayrıca yeni Belediye Kanunu'na eklenen mahalle olmanın nüfus şartı (500 nüfuslu olması) düşünüldüğünde, bu şartı sağlayamayan köylerin durumu meçhul bırakılmıştır.

\subsubsection{Vergi paylaşımı}

Büyükşehir belediyelerinin sınırlarına dahil edilen tüzel kişilikli ya da tüzel kişiliği olamayan yönetim birimlerinde yaşayan vatandaşlar, önceki döneme göre daha fazla vergi ve kullanım ücreti ödemek durumunda kalmıştır. Bu geçiş dönemi sırasında, arsa, arazi ve bina vergileri yeni düzenleme ile büyükşsehir belediyelerinin sınırlarına dahil olan belediyelerde \% 100 artmış; büyükşehir belediyelerine mahalle olarak katılan köylerde yaşayanlar ise daha önce söz 
konusu olmayan emlak vergisi, çevre temizlik vergisi gibi yeni vergiler ödemek zorunda bırakılmışlardır. Bunun dışında su ve kanalizasyon gibi benzeri hizmetleri bundan sonra BŞB'den almak durumunda bırakılan halk, bu hizmetlerin bedelini de ödemek zorunda bırakılmıştır. BŞB'ye dahil edilen yerlerde yaşayan vatandaşlar daha önce ödedikleri vergilerin iki katı kadar fazla vergi ödemek durumunda kalmışlardır. Bunun dışında, yapılan reform çalışmasının devlet bütçesine ve dolayısıyla da vatandaşlara olan maliyeti oldukça büyüktür. İçişleri Bakanlığı Mahalli İdareler Genel Müdürlüğü yetkililerinin yapmış olduğu açıklamalara göre bu rakam yaklaşık olarak 3.012.633.480 TL’dir (Bilmez, 2013).

\subsubsection{Orman Köyü Hususu:}

Köylerin tüzel kişiliği kaldırılmış, hukuk düzlemde, hem idari hem de mali açılardan yok hükmüne düşürülmüştür. Bu nedenle köy tüzel kişiliği varken tanınan kanuni yetkilerinin devam edeceğini ifade etmenin hukuken geçerliliği, güvenilirliği ve yaptırımı bulunmamaktadır. Yapılan bazı düzenlemelerin, orman tüzel kişiliğinin kaldırılmasıyla ortaya çıkan sorunları telafi etmeyeceği hukuken görülmektedir. (Zengin, 2014:112).

\subsection{Sayılı Kanun'un Uygulanışının İle İlgili Çalışmalar}

6360 Sayılı Kanun yürürlüğe girmesinin ardından uygulama aşamasında bazı çalışmalar yapılmıştır. Bu çalışmalar genellikle, kanunun belediyelerin hizmette etkinlik ve verimlilik açısından yeterliliğini araştırarak kanuna getirilen eleştirileri incelemeye yönelik olmuştur.

Bu çalışmalardan biri Çapar ve Demir (2017)'in “Türkiye'de Büyükşehir Yapılanması ve 6360 Sayılı Kanuna Uygulayıcıların Bakışı” adlı çalışmasıdır. Bu çalışmanın amacı, 6360 Sayılı Kanun'un uygulanmasında karşılaşılan sorunları tespit ederek analizini yapmaktır. Çalışma 13 BŞB ile 19 büyükşehir ilçe belediyesini kapsamaktadır. Çalışmadan elde edilen bulgulara göre, büyükşehir ilçe belediyeleri ile BŞB arasında görev, yetki ve kaynak paylaşımı konularında farklı düşüncelerin olduğu ortaya çıkmıştır. Farklılık arz eden bazı başlıklar özetle şöyledir(Çapar ve Demir, 2017);

- Görev ve yetki; Büyükşehir belediyeler görev, yetki ve kaynak paylaşımının dengeli olduğunu düşünürken, ilçe belediyeleri dengesiz bir paylaşım olduğunu düşünmektedir. İlçe belediyeleri, hizmet ve yetki açısından etkisiz hale getirildiklerini düşünmektedirler.

- İmar ve bayındırlık düzenlemeleri; Büyükşehir belediyeleri, planlama (nazım) yetkisinin yeni yasayla birlikte büyükşehirlere verilmesini doğru bularak şehirdeki ulaşım ve imar planlarında daha doğru kararlar alındığını düşünürken, ilçe belediyeleri 1/5000'lik imar planlarının kendileri tarafından yapılması gerektiğini düşünmektedirler.

- Kaynak dağılımı; Büyükşehir belediyeleri, yeni yasayla birlikte görev alanlarının genişlemesi nedeniyle daha fazla kaynak almaları gerektiğini düşünürken, İlçe belediyeleri ise su ve kanal hizmetleri, otogar, mezarlık, itfaiye, toptancı hali, hayvan pazarı ve mezbaha gibi hizmetlerin büyükşehir belediyelerine verilmemesi gerektiğini söylemişlerdir. $\mathrm{Bu}$ hizmetler ve diğerlerinden ayrılan payların büyükşehir belediyesine kaydırılmasıyla birlikte gelir kaybına uğradıklarını belirtmişlerdir. 
- Kırsal bölge hizmetlerine ulaşım; Yeni yasa ile kırsal bölgelerin büyükşehir belediyelerine katılması, büyükşehir belediyelerince bütünsellik açısından önemli ve gerekli bulunurken teşkilat yapılanması açısından bazı sorunlar olduğunu söyleyen büyükşehir belediyeleri de bulunmaktadır. Bir büyükşehir belediyesi bu durumun ekonomik açıdan da verimli olmadığını söyleyerek bunun tekrar gözden geçirilmesi gerektiğini vurgularken genel olarak bu yeni yapılanmayı büyükşehir belediyeleri tarafından olumlu karşılanmaktadır. İlçe belediyeleri ise bu konuda olumlu düşünmemektedir. Yeni düzenleme ile kırsal kesimlere hizmet vermede yetersiz kalındığını ve etkili bir biçimde hizmet verilemediğini savunmuşlardır.

- Merkez (metropol) ilçeler ile merkez dışındaki ilçeler arasında görev, yetki ve kaynak bakımlarından farklılaştırma ihtiyacı; Bu konuda büyükşehir belediyelerinde bir fikir birliği bulunamamıştır. Bazı büyükşehir belediyeleri, görev, yetki ve kaynak bakımlarından merkez ilçeler ile merkez dışındaki ilçeler arasında farklılık oluşturulmasına ihtiyaç bulunmadığını belirtilirken, bazı büyükşehir belediyeleri farklılık oluşturulmasına ihtiyaç olduğunu savunmuşlardır. Bu hususta ilçe belediyeleri; merkez ilçeler ile merkez dışındaki ilçeler arasında görev, yetki ve kaynak bakımlarından farklılık oluşturulmasının gerekliliğini savunmuşlardır. Aksi halde hizmetlerin etkin ve dengeli olarak yürütülmediğini söylemişlerdir.

- Vatandaşların yerel hizmetlere ulaşması ve yönetime katılımı; Büyükşehir belediyeleri bu hususta, belediyecilik hizmetinde birlik ve bütünlüğün sağladığını ve koordinasyon oluşturulduğunu söyleyerek, daha etkin ve verimli hizmet verilebildiği belirtilmişlerdir. Ancak ilçe belediyeleri ise ihtiyaçların yerel düzeyde belirlenmesi gerektiğini ve hizmeti alan vatandaşların hizmeti veren kişilere/kurumlara kolay ve en kısa sürede ulaşabilmesi amacıyla yerel düzeyde teşkilatlanma ihtiyacının olduğuna vurgu yapmışlardır.

Biricikoğlu ve Duyar (2015)’ın “6360 Sayılı Yasa’nın Genişleyen Büyükşehir Belediyesi Hizmet Sınırının Etkinlik Ve Verimliliğe Etkisi Bağlamında Değerlendirmesi: Sakarya Büyükşehir Belediyesi Örneği” adlı çalışmada 6360 sayılı Kanun ile büyükşehir belediyesi hizmet alanı değişikliğinin Sakarya ölçeğinde etkin ve verimli hizmet sunumuna etkisinin nasıl olduğu araştırılmıştır.Konuyla ilgili araştırma için Sakarya BŞB daire başkanları ile mülakat yoluyla görüşülmüştür. Araştırmada sonuç olarak; 6360 sayılı Kanun ile büyükşehir hizmet alanının coğrafi alan olarak genişlemesinin yani hizmet ölçeğinin büyümesinin Sakarya BŞB'nde hizmetlerin etkinliği ve verimliliği açısından olumlu ve olumsuz sonuçları olduğu gözlenmiştir. Kanun sonrasında Sakarya BŞB hizmet sunumu açısından değerlendirildiğinde, daire başkanlarına göre, hizmetin etkinlik ve verimlilik açısından olumlu sonuçları olmuştur. Ancak bir takım sorunlarında yaşandığını söyleyen daire başkanları, bu sorunların genellikle eski alışkanlıkların sürdürülmeye çalışılmasından kaynaklandığını vurgulamışlardır. Kanunun hizmet talebine ve hizmet sunma kapasitesine olan etkisine bakıldığında ise hizmet talebinde bir artışın gözlendiği ancak bu taleplerin karşılanabilir nitelikte olduğu belirtilmiştir. Bunun yanında hizmet sunma kapasitesinde bir takım sorunların bulunduğu da görülmüştür. Bu sorunlar genellikle idari personel ve mali kaynak yetersizliğinden kaynaklanmaktadır. Sakarya BŞB'ndeki daire başkanları arasında hizmet maliyetlerindeki artışa cevap verebilecek nitelikte olduğunu düşünenleri sayısının daha fazla olduğu görülmüştür. Ancak büyük çevresel projelerin talep edilmesi noktasında ciddi bir sorun olduğu da belirtilmiştir. 
Biricikoğlu ve Yalnızoğlu (2018)'nun yapmış olduğu “6360 Sayılı Kanun’un Etkinlik-Verimlilik İle Hizmette Yerellik İlkeleri Açısından Değerlendirilmesi: Kocaali İlçesinde Yapılan Bir Araştırma” adlı çalışmada, yeni kanun sonrasında 16 ilçeye ve yaklaşık 977.000 kişiye hizmet verenSakarya Büyükşehir Belediyesi’nin hizmette etkinlik ve verimliliği incelenmiştir. Araştırmada Sakarya BŞB’nin etkinlik ve verimliliği iki açıdan ele alınmıştır. Öncelikle yeni kanun sonrasında Kocaali’nde büyük bütçe gerektirdiği için hayata geçemeyen projelerin Sakarya BŞB tarafindan yapıldığı ve bu sayede ilçeler arası eşitsizliğin ortadan kalktığı görülmüştür. Ancak bunun yanı sıra diğer açıdan bakıldığında daha önceleri iş özel idareleri tarafından hizmet götürülen kırsal alanlara hizmetin götürülmesi bakımından etkinlik ve verimliliğin sağlanmasında sorunlar yaşandığı görülmüştür. Kocaali ilçesinin gerek muhtarları gerekse diğer yöneticileri, ilçenin bu hizmetler konusunda geri kaldığını vurgulamışlardır. Bunun yanında yeni kanun sonrasında mali yapıda yapılan değişiklikler ile ilçe belediyelerine ayrılan payların nüfusa göre belirenmesi Kocaali ilçesi için sorun yaratmıştır. Bunun nedeni, Kocaali ilçesinin yaz ve kış nüfusunun farklı oluşudur. Bu durum Kocaali ilçesini, mali açıdan zayıflatarak hizmetlerin etkin ve verimli bir şekilde yürütülmesi konusunda dezavantajlı hale getirmiştir.

\section{SONUÇ}

6360 Sayılı Kanun'un temelde iki önemli amacı bulunmaktadır. Bunların ilki, hizmet sunumu açısından en etkili ve verimli yönetsel yapıyı inşa etmektir. İkincisi ise kanunun meydana çıkardığı yeni yerel yapı ile demokratik katılımı arttırmaktır. Bu şekliyle kanunun olumlu getirileri olacağı düşünülmüştür. Ancak bunun yanı sıra kanun gerek barındırdığı değişiklikler ile gerekse uygulamadaki endişe yaratan düzenlemeleriyle önemli eleştirilere de maruz kalmıştır.

6360 Sayılı Kanun’nun BŞB sınırlarını il mülki sınırları ile örtüştürmüş olduğundan, yapılan düzenlemenin ileride sorun yaratacağı düşünülmüştür. Kanun, getirdiği yeni düzenlemeler ile yerel siyasal hayatta beklenmedik sonuçların ortaya çıkmasına sebep olabileceği gibi birtakım yeni, kentsel, toplumsal ve yönetsel sorunların da yaşanmasına neden olabilecektir. Çünkü bu kanun ile geleneksel yerel yönetim birimleri (belde belediyesi, il özel yönetimleri, köyler) ortadan kaldırılmış ve hizmet üreten tek yerel yönetim birimi olarak BŞB’lerini belirlemiştir. İl sınırları dahilinde yerel halkın gereksinimlerinin farklılaştığı birimler bulunmaktadır. Kanun ile bu birimlerdeki halka hizmet veren yönetim birimlerinin tüzel kişiliklerine son verilmiştir. Böylelikle hizmete yakınlık sorunu ortaya çıkmış bir nevi uzaktan kumandalı hizmet anlayışı benimsenmiştir. Bu yeni yapı içerisinde hem etkili ve kaliteli hizmet sunumu hem de demokratik katılım gibi pek çok sorun ortaya çıkmıştır. BŞB sınırlarının, (kentsel alan olsun olmasın) coğrafi açıdan genişletilerek il mülki sınırları ile örtüştürülmesi, bazı kırsal bölgelerde yaşamı kolaylaştırsa da birçoğunda zorlaştıracağ 1 öngörülmektedir. Yeni kanun gereğince bu bölgelerde yaşamakta olan halk, daha önce karşılaşmadığ vergi, harç, katılım payı gibi önemli miktarda ödemelerle karşı karşıya kalmış ve kullanım ve içme suyu için yüksek ücretler ödemek zorunda kalmışlardır. Böylece kırsal bölgelerde üretim ve yaşamı daha da zor hale getirmiş ve eskiden beri süregelen yoksulluk artmaya başlamıştır. Türkiye'de kırsal bölgelerden şehirlere göç uzun süredir önemli bir sorun olmuştur. Yeni kanun ile bu göç dalgasının artması kaçınılmaz görülmektedir. 
Yerel özerklikten gelinen nokta, 6360 Sayılı Kanun ile yasal olarak aşırı güçlendirilmiş yeni merkezciklerin ihdası olmuştur. İstanbul ve diğer tüm büyükşsehirler, kendilerine bağlı tüm yerel birimleri katı bir merkeziyetçilikle yönetir hale gelmiştir. Neredeyse yarısı kırsal alan ve nüfustan oluşan birçok büyükşehir, köyleri ve birçok belediyeyi lağv ederek yerelin hem seçmenini, hem mali kaynaklarını hem de sosyal haklarını bir anlamda gasp etmiştir. Büyükşehir merkezinden onlarca km uzaklıktaki yerel birimlerin en basit mahalli ihtiyaçları, Ankara'dan kurtarılmış ama başka bir merkeziyetçi anlayışın tasarrufuna bırakılmıştır.

\section{KAYNAKLAR}

Anas, Bircan ve İnci, Nezaket (2014). "Merkezi İdari ile Mahalli İdareler Arasındaki Görev ve Gelir Bölüşümü”, Balıkesir Üniversitesi Bandırma İktisadi Bilimler Fakültesi Maliye Bölümü, Lisans Tezi, Bandırma.

Arıkboğa, Erbay, (2013). “Geçmişten geleceğe büyükşehir belediye modeli, Yerel Politikalar”, Ocak- Haziran 2013, 48-96.

Bilmez, Mehmet Emin, (2013). Büyükşehir Kanunu Eğitimi (Sunu), Türkiye Belediyeler Birliği, Ordu 2013. http://www. tbb.gov.tr/belediye-akademisi/sunumlar/ (18.6.2019).

Biricikoğlu, Hale ve Duyar, Demirol (2015) “6360 Sayılı Yasa'nın Genişleyen Büyükşehir Belediyesi Hizmet Sınırının Etkinlik Ve Verimliliğe Etkisi Bağlamında Değerlendirmesi: Sakarya Büyükşehir Belediyesi Örneği”. Süleyman Demirel Üniversitesi İktisadi ve İdari Bilimler Fakültesi Dergisi Y.2015, C.20, S.4, s.369-393.

Biricikoğlu, Hale ve Yalnızoğlu, Yasemin (2018). “6360 Sayılı Kanun’un Etkinlik-Verimlilik İle Hizmette Yerellik İlkeleri Açısından Değerlendirilmesi: Kocaali İlçesinde Yapılan Bir Araştırma”Yönetim Bilimleri Dergisi /Journal of Administrative SciencesCilt/Volume 16, Say1/N: 32 ss.pp.: 255-284- 2018

Can, Ergüder, (2013). “6360 Sayılı Kanun Ve Yerel Yönetimlerde Yeni Dönem”, F. N. Genç (Ed.) içinde, Yönetişim, Türk Kaти Yönetimine Yansımaları, ss. 265 - 275, Çizgi Kitabevi, Konya.

Çapar, Selim ve Demir, Recep (2017) “Türkiye'de Büyükşehir Yapılanması Ve 6360 Sayılı Kanuna Uygulayıcıların Bakışı” Türk İdare Dergisi, Sayı, 484.

Çınar, Tayfun, Bülent Duru, Can Umut Çiner, Ozan Zengin (2013). "Belediyenin Sınırları”, TODAİE, Ankara

Güler, B. Ayman (2012) "Büyükşehir Kanun Tasarısı İçişleri Komisyonunda Görüşülüyor", http://www.yayed.org/uploads/yuklemeler/B\%C5\%9EB\%20KOM\%C4\%B0SYONDA.p df, (11.02.2019). 
Karaaslan, Mehmet (2013). "Nasıl Bir Yerel Yönetim? 6360 Sayılı Kanun Üzerine Bir Değerlendirme” Dicle Üniversitesi Hukuk Fakültesi Dergisi, Cilt: 17-18, Sayl: 26-27-28-29,

Özer, M. Akif, (2013). "Yerel Yönetimler Reformunda Reform: 6360 Sayılı Kanun’un Düşündürdükleri, Yerel Politikalar”, Ocak - Haziran 2013, 97-126, Çizgi Kitabevi, Konya.

Tekin, Ömer Faruk (2018). “Türkiye’de Büyükşehir Yönetimi Ve 6360 Sayılı Yasanın Getirdiği Değiş̧im: Konya Örneği” Dumlupınar Üniversitesi Sosyal Bilimler Dergisi, Sayı:55, Ocak, Kütahya.

Yıldırım, Uğur ve Belli, Aziz, (2013). "Yeni Büyükşehir Belediyesi Yönetim Modelinin Metropoliten Alan Kavramı Açısından Değerlendirilmesi”, Kuramdan Uygulamaya Yerel Yönetimler veKentsel Politikalar (Ed.: Y. Bulut, V. Eren, S. Karakoç, A. Aydın), ss: 97-111, Pegem Akademi, Ankara

Zengin, Ozan (2014). “Büyükşehir Belediyesi Sisteminin Dönüşümü: Son On Yılın Değerlendirmesi” Ankara Barosu Dergisi, Sayı:2 Ankara. 